\title{
The Relationship of Service Quality on Consumer Satisfaction in Shipyard Industry
}

\author{
Suharto $^{1} \&$ Sulistiyono ${ }^{1}$ \\ ${ }^{1}$ Faculty of Engineering, Diponegoro University, Semarang, Indonesia \\ Correspondence: Suharto, Faculty of Engineering, Diponegoro University, Semarang, Central Java, 50275 \\ Indonesia. Tel: 62-247-460-053. E-mail: suharto2008@ymail.com
}

Received: May 17, 2015

doi:10.5539/mas.v9n11p247
Accepted: May 31, $2015 \quad$ Online Published: September 30, 2015

URL: http://dx.doi.org/10.5539/mas.v9n11p247

\begin{abstract}
Service quality and customer satisfaction have become a widely discussed issue for two decades. However, only a few intention used shipyard as the marketing researches target of these variables. The authors investigate the relationships between service quality dimensions and consumer satisfaction in shipyard industry. The authors test the significance of the relationships between service quality dimensions and consumer satisfaction. The results suggest that four service quality dimensions (tangible, responsibility, responsiveness and assurance) are antecedents of consumer satisfaction in this industry, while empathy has less effect on satisfaction. Implications for managers and future research are discussed.
\end{abstract}

Keywords: service quality, customer satisfaction, shipyard industy

\section{Introduction}

Service quality are increasingly changing the way firms interact with customers to create service outcomes. Level of interact is described as the extent of interpersonal interaction between the customer service and service satisfaction (Bearden, Malhotra, \& Uscátegui, 1998; Bitner, Brown, \& Meuter, 2000; Kim, Park, \& Jeong, 2004; Guenzi \& Pelloni, 2004). Since a basic characteristic of services is the participation of the customer in the production process, the customer is said to be an important resource of the service firm (Gouthier \& Schmid, 2003; Walsh \& Beatty, 2007; Hartline, Maxham III, \& McKee, 2000). Many companies consider their quality of service as means of increasing customer commitment and building customer loyalty.

Excellence in customer service is the hallmark of success among manufacturers of products and service industries (Parasuraman, Zeithaml \& Berry, 1990; Parasuraman, 2000; Zeithaml, 2002; Johnston, 2004). Customers will compare their perceptions with expectations when judging a firm's service. Hence understanding customer expectations is a prerequisite for delivering superior service (Robledo, 2001; Parasuraman, Berry, \& Zeithaml, 1991; Ulaga \& Chacour, 2001). Customer's satisfaction with a service failure encounter affect cumulative satisfaction judgments and repatronage intentions. Woodruff, Cadotte, and Jenkins (1983) stated that satisfaction process is more likely to be raised to a conscious level and thus evoke a positive or negative emotional response. Thus, positive or negative satisfaction should increase negative word-of-mouth and consumer's likelihood of reacting in product purchasing. Receiving negative and positive word-of-mouth from satisfied and dissatisfied customers influences the potential customer can create cost/benefit and have consequences toward customer extra-role behavior (i.e, customer citizenship behavior and badness behavior) (Yi \& Gong, 2006). Due to customers often react strongly to service failures, so it is critical that an organization's responsiveness efforts be equally strong and effective.

Researchers and managers pay increasing attention to relationship of service quality and customer satisfaction (e.g Cronin, Brady, and Hult, 2000; Sureshchandar, Rajendran, \& Anantharaman, 2002; Sivadas \& Baker-Prewitt, 2000; González, Comesana, \& Brea, 2007; Caruana, 2002; Olorunniwo, Hsu, \& Udo, 2006; Tam, 2004; Eboli \& Mazzulla, 2007; Siddiqi, 2011; Murray \& Howat, 2002; Al-Hawari \& Ward, 2006, Hu, Kandampully, \& Juwaheer, 2009; Kouthouris \& Alexandris, 2005; Yang \& Fang, 2004). They have become a widely discussed issue for decades, both theory and practice. In service environments, customer satisfaction and service quality are widely recognized as valuable variables in the formation of consumers' purchase intentions (Cronin et al. 2000; Maxham, 2001; Kuo, Wu, \& Deng, 2009; Olorunniwo, et al., 2006; González,et al., 2007; Bai, Law \& Wen, 2008; Murray \& Howat, 2002; Baker \& Crompton, 2000; Brady, Robertson, \& Cronin, 2001; 
Tsiotsou, 2006). As in the case in most other service industries, customer satisfaction is of paramount importance in the shipyard industry. Customer satisfaction management in the shipyard service industry is difficult due to the diversity of services and the massive of technology adoption. However, only a few intention used shipyard as the marketing researches target of these variables. Therefore, to fill this practice gap, this study has objective to examine the influence of service quality on customer satisfaction in shipyard industry.

\section{Literature Review}

\subsection{Service Quality}

Service quality has impact on customers' behavioral responses and intention. It relates to retention of customers at the aggregate level (Zeithaml et al., 1996; Woodside, Frey \& Daly, 1990). While perceived service quality is a consumer judgement (a form of attitude) and resulted from comparisons consumers make between their expectations and their perception of the actual service performance (Zeithaml, 1988; Bahia \& Nantel, 2000; Caruana, 2002). One effective means of achieving competitive advantage and differentiating strategies involves superior service quality (Yang \& Fang, 2004). Service quality has examined customer evaluations of the overall excellence or superiority (Long \& McMellon, 2004). The basis of this theory is the definition of service quality as the "overall excellence or superiority" (Brady \& Robertson, 2001). Service quality can be described as overall customer judgments and evaluations regarding the quality and excellence of service. According to these arguments, Santos (2003) defined service quality as the overall evaluation of service performance.

Services characterized as intangible, activities rather than things, produced and consumed simultaneously and the customer participates in the production process (Gronroos, 1988). Hence, in the shipyard context physical environment of service quality settings affect customers' evaluations of the service experience and subsequent behavioral intentions. Kelley and Davis (1994) proposed a conceptual model in which customer perceptions of service quality relates with customer satisfaction, and customer organizational commitment function. Through qualitative and empirical research, Brady and Cronin (2000) found that the service quality construct conforms to the structure of a third-order factor model that ties service quality perceptions to distinct and actionable dimensions: outcome, interaction, and environmental quality. Futhermore, these subdimensions can contribute to improve service quality perceptions. Satisfying customers is only the base line and may not be sufficient for survival. Management should focus on gaining customer loyalty by enhancing customer perceptions of service quality (Hu et al., 2009). The quality received by consumers must be perceived to be responsive, empathetic and reliable.

Parasuraman et al. (1991) measured service quality with five dimensions: asssurance, reliability, empathy, responsiveness, tangibles. Kim, Suh and Hwang (2003) elaborates these dimensions. Assurance defined as knowledge and courtesy of employees and their ability to inspire trust, and confidence. Reliability is ability to perform the promised service dependably and accurately. Empathy is caring, individualized attention the service provider gives its customers. Responsiveness described as willingness to help customers and provide prompt service. Tangibles is physical facilities, equipment,and appearance of personnel.

\subsection{Customer Satisfaction}

Consumer satisfaction is a central concept in modern marketing thought and practice. Many service companies have embraced relationship marketing with its focus on maximizing customer lifetime value and linking between customer satisfaction and purchase retention (Bolton, 1998). In the formal definition, customer satisfaction defined as the differences between consumers' perceptions and expectations of service quality they received (Bishop-Gagliano \& Hathcote, 1994). Cardozo (1965) indicates customer satisfaction with a product is influenced by the effort expended to acquire the product, and the expectations concerning the product. Customer satisfaction with a particular brand is a function of all past, current, and future experience (Anderson, Fornell, \& Lehmann, 1994). Fornell (1992) describes customer satisfaction as a function of customer expectations and perceived performance of the product or services (customer satisfaction $=\mathrm{f}$ (expectations, perceived performance)). Customer satisfaction is related to the size and direction of disconfirmation, which is defined as the difference between an individual's pre-purchase expectations (or some other comparison standard) and post-purchase performance of the product (Patterson, Johnson, \& Spreng, 1996). Based on theory from consumer behavior and cognitive psychology, Wallin and Lindestad (1998) interviewed 600 individual customers to examine corporate image and customer satisfaction as two routes to customer loyalty, and to actual repurchase behavior. Lee, Lee, and Feick (2001) stated that customer satisfaction programs can increase customer retention rates.

Satisfaction are extremely important concepts as academic researchers, particularly in services marketing, and to practitioners as a means of creating competitive advantages and customer loyalty. Customer satisfaction with a company's products or services is often seen as the key to a company's success and long-term competitiveness 
(Hennig-Thurau \& Klee, 1997). In the context of relationship marketing, customer satisfaction is often viewed as a central determinant of customer economic benefits for improving customer satisfaction. Shemwell, Yavas, and Bilgin (1998) found that customer-service has relationships with satisfaction and relationship-oriented outcomes. Customer satisfaction is service firm's s capacity to meet customer expectations. So, many firms that are frustrated in their efforts to improve quality and customer satisfaction are beginning to question the link between customer satisfaction and economic returns. Dissatisfied customers do engage in greater word of mouth than satisfied ones (Anderson, 1998).

\subsection{Service Quality and Customer Satisfaction: The Interrelationship}

Service quality and customer satisfaction are widely recognized as key influences in the formation of consumers' purchase intentions in service environments (Taylor \& Baker, 1994). Perceived service quality and satisfaction have generally been conceptualized to be distinct constructs, but there isn't a good understanding of their relationship (Spreng \& Mackoy, 1996). By examining the effect of 3 customer service variables (on-time performance, mishandled baggage, and ticket over-sales) on customer satisfaction and in turn on profitability for US airlines, Dresner and Xu (1995) found that service quality has relationship with customer loyalty in the commercial airline industry. Similarly, Steven, Dong, and Dresner (2012) investigates the linkages between customer service, customer satisfaction and firm performance in the US airline industry. In particular, the moderating effects of market concentration and firm dominance on the service-satisfaction-performance relationship. Yeo, Roe, and Dinwoodie (2008) measure quality of port service in China and Korea including prompt response, $24 \mathrm{~h}$ a day, seven days a week service and zero waiting time service.

Johnston (1995) stated that attentiveness, responsiveness, care and friendliness; and the dissatisfiers are integrity, reliability, responsiveness, availability and functionality are the predominantly satisfying determinants. Responsiveness is identified as a crucial determinant of quality as it is a frequent source of satisfaction, and the lack of it is a major source of dissatisfaction. Furthermore, reliability is predominantly a source of dissatisfaction not satisfaction.

Blodgett, Granbois, and Walters (1994) revealed the importance of customer service and customer satisfaction, especially since the cost of keeping a current customer satisfied is much less than the cost of attracting a new customer. Innis and Londe (1994) found that customer service is the key to customer satisfaction, customer loyalty, and market share. Salanova, Agut, and Peiro (2005), by interviewing 342 employees from 114 service units (56 restaurants and 58 hotel front desks) found the mediating role of service climate in the prediction of employee performance and customer loyalty. In explaining the link between customer satisfaction and loyalty, switching costs play an important role. Using a national random telephone survey of 542 shoppers, Sivadas and Baker-Prewitt (2000) examines the relationship between service quality, customer satisfaction, and store loyalty within the retail department store context. Lee, Lee, and Yoo (2000) and Caruana (2002) found the relationship of service quality with satisfaction. Cronin et al. (2000) conceptualizes the effects of quality, satisfaction, and value on consumers' behavioral intentions. The results suggest that service quality is an antecedent of consumer satisfaction, a performance-based measure of service quality may be an improved means of measuring the service quality construct, consumer satisfaction has a significant influence on purchase intentions, and service quality has less effect on purchase intentions than does consumer satisfaction.

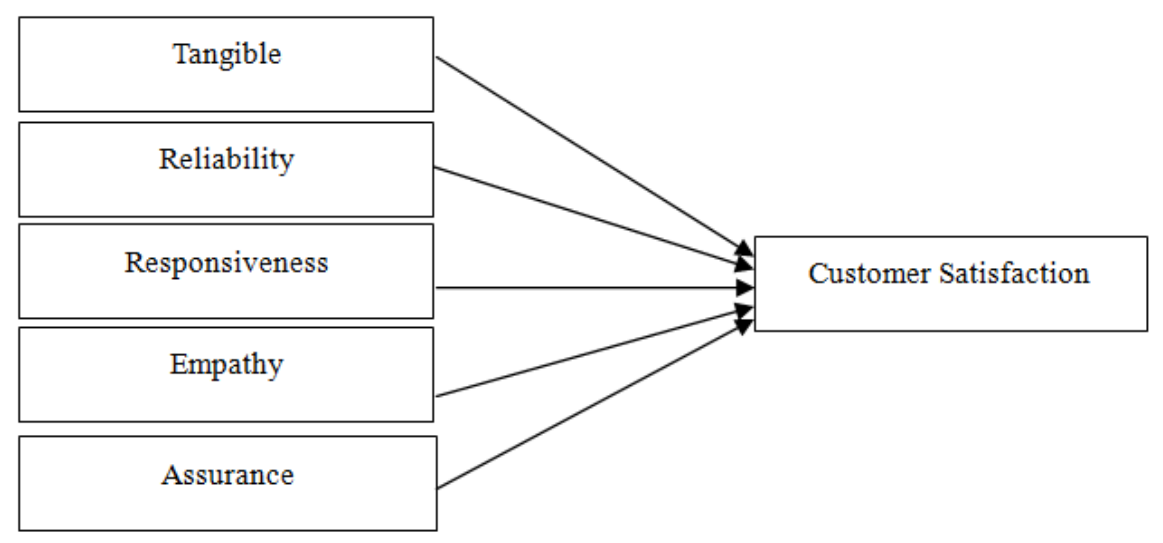

Figure 1. Conceptual Model 


\section{Methodology}

This research was conducted in Janata Marina Indah shipbuilding company which based in Tanjung Emas Port of Semarang. Research was conducted by explorative research through a quantitative approach. Sampling for this research was used random sampling method. A total of 36 service quality questionnaires with ten-point interval of Likert's rating scales were collected from ship owners were completed and collected. Satisfaction with the single attributes as well as overall satisfaction with the service was measured using a ten-point Likert scale. The regression analysis was adopted to test the relationship of service quality and customer satisfaction. This research uses reliability to assess the degree of consistence variable. Measurement of the degree of consistence of variables is used Cronbach's $\alpha$ values. A higher correlation of respective variables coefficient represents a higher reliability. To show how valid a questionnaire is, this study measures variable characteristics of content validity.

Table 1. Measurement for Dimensions

\begin{tabular}{ll}
\hline Dimensions & Operational Measurement. \\
\hline Tangibles & Physical facilities, equipment,and appearance of personnel (Kim et al., \\
& 2003). This study measures tangibles with quality of shipyard facilities and \\
& equipments. \\
& Ability to perform the promised service dependably and accurately (Kim et \\
Reliability & al., 2003). This study measures reliability with accuracy of processing time \\
& of engineering works in shipyard and on time ship delivery. \\
& Willingness to help customers and provide prompt service (Kim et al., \\
Responsiveness & 2003). This study measures responsiveness with promptness to serve \\
& shipyard costumers in general services (ccommodation, sanitary, information \\
& and communication). \\
& Knowledge and courtesy of employees and their ability to inspire trust, and \\
Assurance & confidence (Kim et al., 2003). This study measures assurance with quality of \\
engineering works in shipyard. & Individualized attention and caring the service provider gives its customers \\
Empathy & (Kim et al., 2003). This study measures empathy with quality of general \\
& services (ccommodation, sanitary, information and communication). \\
& Customer satisfaction = f(expectations, perceived performance). This study \\
conducted customer satisfaction with a particular brand as a function of all \\
past, current, and future experience of shipyard customers (Anderson et al., \\
\end{tabular}

\section{Finding}

\subsection{Reliability and Validity Analysis}

Reliability is a measuring tool contains a level of variable error. Cronbach's $\alpha$ values are commonly used to measure the degree of consistence of various facets in the same dimension. The questionnaire includes a variety of dimensions, and a higher reliability coefficient represents a higher correlation of respective dimensions, which illustrates higher internal consistence. When Cronbach's $\alpha$ value is greater than 0.7 , it is referred to as high reliability. The results of the questionnaire reliability analysis show that the Cronbach's $\alpha$ value is 0.822 . Given its variables all reaching a level of high reliability, it illustrates that the overall consistence of the questionnaire of this study is in high reliability.

Table 2. Reliability Statistics

\begin{tabular}{cc} 
Cronbach's Alpha & N of Items \\
\hline .822 & 6 \\
\hline
\end{tabular}

To show how valid a questionnaire is, it is necessary to measure variable characteristics and it would meet the requirement of content validity. Item-correlation values are commonly used to measure validity in contexts 
where a number of tests or questions are given to an individual and where the problem is to construct a useful single quantity for each individual that can be used to compare that individual with others in a given population A small item-correlation provides empirical evidence that the item is not measuring the same construct measured by the other items included. A correlation value less than 0.2 or 0.3 indicates that the corresponding item does not correlate very well with the scale overall and, thus, it may be dropped. According to the analysis, the study shows that the values of its respective dimensions are all greater $\mathrm{r}$ table ( $\mathrm{r}$ values of Corrected Item-Total Correlation $>\mathrm{r}$ TABLE 0.378). Each facet's factor loading is between 0.465 and 0.842 for responsiveness and satisfaction respectively. This result illustrates that the questionnaire used in this study meet the requirement of construct validity.

Table 3. Item-Total Statistics

\begin{tabular}{lrrrr}
\hline & $\begin{array}{c}\text { Scale Mean if } \\
\text { Item Deleted }\end{array}$ & $\begin{array}{c}\text { Scale Variance if } \\
\text { Item Deleted }\end{array}$ & $\begin{array}{c}\text { Corrected Item-Total } \\
\text { Correlation }\end{array}$ & $\begin{array}{c}\text { Cronbach's Alpha if } \\
\text { Item Deleted }\end{array}$ \\
\hline Reliability & 36.0556 & 6.797 & .689 & .772 \\
Tangible & 37.1111 & 8.502 & .568 & .802 \\
Responsiveness & 36.7222 & 7.863 & .465 & .824 \\
Assurance & 36.4722 & 7.171 & .591 & .797 \\
Empathy & 37.0000 & 8.857 & .479 & .816 \\
Satisfaction & 37.4722 & 7.285 & .842 & .745 \\
\hline
\end{tabular}

\subsection{Correlation Analysis}

This study uses Pearson's correlation analysis to confirm the correlation of two dimensions and the correlation coefficients of respective variables as shown in Table 3. As the data shown in Table 3, reliability and assurance and satisfaction; tangible and responsiveness, assurance, empathy and satisfaction; responsiveness and empathy and satisfaction; assurance and satisfaction, those are significant positive correlation. While tangible for reliability, responsiveness for reliability, assurance for responsiveness, empathy for reliability and assurance and satisfaction are not significant positive correlation.

Table 4. Pearson Correlations

\begin{tabular}{|c|c|c|c|c|c|c|}
\hline & & Reliability & Tangible & Responsiveness & Assurance & Empathy \\
\hline \multirow[t]{2}{*}{ Tangible } & Pearson Correlation & .319 & & & & \\
\hline & Sig. (2-tailed) & .058 & & & & \\
\hline \multirow[t]{2}{*}{ Responsiveness } & Pearson Correlation & .314 & $.413(*)$ & & & \\
\hline & Sig. (2-tailed) & .062 & .012 & & & \\
\hline \multirow[t]{2}{*}{ Assurance } & Pearson Correlation & $.769(* *)$ & $.365\left(^{*}\right)$ & .110 & & \\
\hline & Sig. (2-tailed) & .000 & .029 & .522 & & \\
\hline \multirow[t]{2}{*}{ Empathy } & Pearson Correlation & .191 & $.670(* *)$ & $.564(* *)$ & .220 & \\
\hline & Sig. (2-tailed) & .263 & .000 & .000 & .198 & \\
\hline \multirow[t]{2}{*}{ Satisfaction } & Pearson Correlation & $.830(* *)$ & $.485(*)$ & $.552(* *)$ & $.704(* *)$ & .292 \\
\hline & Sig. (2-tailed) & .000 & .003 & .000 & .000 & .084 \\
\hline
\end{tabular}

Note : ** Correlation is significant at the 0.01 level (2-tailed). * Correlation is significant at the 0.05 level (2 tailed).

\subsection{Hypotheses Testing}

1) Examination of regression analysis results the strongly significant positive relationship between four of customer satisfaction dimensions (reliability, tangible, responsiveness and assurance). Table 5 shows beta coefficient of these variables are high, where standardized coefficients for reliability $(0.460)$, tangible (0.230), responsiveness $(0.422)$, and assurance $(0.275)$ and are significant at $\mathrm{p}<0.05$. Moreover, H0 will be 
rejected as there are significant effect of those variables to customer satisfaction.

2) The second regression between empathy and satisfaction shows a negative relationship even though significance value $(0.029)$ shows favourable into the model $(p<0.05)$. Hence, Ha will be rejected as there is negative effect of empathy to customer satisfaction.

Table 5. Coefficients(a)

\begin{tabular}{|c|c|c|c|c|c|c|}
\hline Model & & Unstandardizec & d Coefficients & Standardized Coefficients & $\mathrm{t}$ & Sig. \\
\hline \multirow[t]{6}{*}{1} & (Constant) & $\begin{array}{l}\text { B } \\
.065\end{array}$ & $\begin{array}{l}\text { Std. Error } \\
\quad .710\end{array}$ & Beta & $\begin{array}{l}\mathrm{B} \\
.092\end{array}$ & $\begin{array}{r}\text { Std. Error } \\
.927\end{array}$ \\
\hline & Reliability & .347 & .092 & .460 & 3750 & .001 \\
\hline & Tangible & .264 & .116 & .230 & 2272 & .030 \\
\hline & Responsiveness & .335 & .075 & .422 & 4448 & .000 \\
\hline & Assurance & .207 & .091 & .275 & 2269 & .031 \\
\hline & Empathy & -.296 & .129 & -.249 & -2293 & 029 \\
\hline
\end{tabular}

a. Dependent Variable: Satisfaction

Nonetheless, the effect of five dimensions of service quality to customer satisfaction is still shows a significant result as can be seen from the ANOVA result where significant at $0,00(p<0.01)$. One thing can be concluded here is, service quality has a significant effect to the probability of a customer satisfaction negatively, notably in empathy dimension. However, the sensitivity of this model is strong.

Table 6. ANOVA(b)

\begin{tabular}{llrrrrr}
\hline Model & & Sum of Squares & df & Mean Square & F & \multirow{2}{*}{ Sig. } \\
\hline 1 & Regression & 13.246 & 5 & 2.649 & 33.207 & $.000(\mathrm{a})$ \\
& Residual & 2.393 & 30 & .080 & & \\
& Total & 15.639 & 35 & & & \\
\end{tabular}

a. Predictors: (Constant), Empathy, Reliability, Responsiveness, Tangible, Assurance

b. Dependent Variable: Satisfaction

The standardized regression coefficients are used as measures of attribute importance. Table 7 shows high effect between service quality and customer satisfaction with adjusted $R 2$ is 0.821 . This result implicitly derived importance was measured using multiple regression analysis. The result shows that higher service quality score will effect positively on customer satisfaction while empathy will effect satisfaction negatively. Overall satisfaction was regressed on the five attributes of service quality.

Table 7. Model Summary

\begin{tabular}{rrrrr}
\hline Model & R & R Square & Adjusted R Square & Std. Error of the Estimate \\
\hline $.920(\mathrm{a})$ & .847 & .821 & .28245 \\
\hline
\end{tabular}

a. Predictors: (Constant), Empathy, Reliability, Responsiveness, Tangible, Assurance.

\section{Discussion}

The positive relationship of four service quality attributes (reliability, tangible, responsiveness, and assurance) and customer satisfaction are fully supported. The findings of this study are not exactly in line with Woodside et al. (1990) viewpoints which link the relationships among service quality, customer satisfaction, and behavioral 
intention for service purchases. Brady et al. (2001) found that both service quality and service value lead to satisfaction. Service quality, service value, and satisfaction may all be directly related to behavioral intentions when all of these variables are considered collectively.

The empathy does not have positive relationship with the customer satisfaction dimension. As stated above that empathy is individualized attention and caring the service provider gives its customers (Kim et al., 2003). This study measures empathy with quality of general services (accomodation, sanitary, information and communication). This result in line with Chung and Lee (2003) research that responsiveness, assurance, reliability, tangibility have positive effect on the level of overall satisfaction, while empathy has negative effect of credit card use. While Yavas, Bilgin, and Shemwell (1997) show that tangibles, responsiveness and empathy are significant predictors of consumer satisfaction. Similarly Pleger (2000) stated that consumer's expectations of reliability, responsiveness, assurance and empathy were all higher for the intangible services in the telephone company. Cheung and Lee (2005) found that among the five dimensions of SERVQUAL, only assurance and empathy are significant determinants in explaining customer satisfaction.

Hence, consumers might have different feelings general services quality of Janata Marina Indah Shipyard. For example, consumers tend to have slightly feeling on other attributes of service quality of shipyard, but they did not feel individualized attention. This might due to such engineering works characterized in shipyard industry as bilge and tank cleaning, operation of diesel and gasoline engines, boiler operation, fiberglass lay-up abrasive blasting, coating application, oil transfer operations, and service of refrigeration units. Hence, customer satisfaction does not meet with the individual hospitality and lack of individual attention of shipyard workers. For this industry, service quality and customer satisfaction relates on the physical environment and instruments dimensions.

This result confirms LeBlanc and Nguyen (1988) that perceived quality depend on the degree of customer satisfaction, the contact personnel, the internal organisation, the physical environment and instruments, the corporate image, and the personnel/customer interaction during the service encounter. While Kara, Lonial, Tarim, and Zaim (2005) stated that intangible factors turn out to be among the most decisive ones in determining the service quality.

\section{Conclusion and Implication}

A multiple regression analysis was conducted and five attributes were found to have a significant impact on customer satisfaction dimensions of reability, tangibles, responsiveness, and assurance. While empathy has significant negative effect on shipyard customer satisfaction. The major findings of this study were listed as follows:

1) There is a significantly positive relationship between reliability and customer satisfaction.

2) There is a significantly positive relationship between tangible and customer satisfaction.

3) Responsiveness has a significantly positive influence on satisfaction.

4) Assurance has a significantly positive influence on shipyard customer satisfaction.

5) There is a significantly negative relationship between empathy and customer satisfaction.

Practical implications are clear. This study verifies the importance for shipyard managers to design a holistic approach to empathy to customers in their processing time. Empathy focuses on the care and individual attention to customers (Cheung \& Lee, 2005). Empathy requires exclusive treatment of actual caring responses and consumer interactional fairness. Regarding the consumer's view, empathy was the most frequently mentioned construct. Consumers expect to get individual attention from firms with whom they have a relationship. They like the businesses to know who they are and their needs (Sorce \& Edwards, 2004). Shipyad marketers understanding of empathy could affect consumer behavior in directly by making salient to the consumer the product benefits that are being enjoyed by other consumers (Bickart \& Schindler, 2001). Sharma (2001) stated that when a consumer meets a salesperson demonstrating no empathy or demonstrating negative affect, the consumer will likely believe that the salesperson does not have his/her interest in mind.

Marketers of shipyard industry must consider improving not only service quality and customer satisfaction but also perceived customer value. Oh (1999) stated that ignoring customer value may cause lowered customer satisfaction and reduced repeat business. Hence, shipyard industries require to expand facilities, update services and promote marketing, service, rapidity of processing, simplicity of documentation and labour skills.

Future research may wish to consider other shipbuilder or shipyard industry services. Service quality as known to have multidimensional facets, have to measured by multi-item measurement. This study used single-item 
overall measurement for most variables, as the primary focus of the study was to provide an approach of service quality and customer satisfaction research in shipyard industry.

\section{References}

Al-Hawari, M., \& Tony, W. (2006). The effect of automated service quality on Australian banks' financial performance and the mediating role of customer satisfaction. Marketing Intelligence \& Planning, 24(2), 127-147. http://dx.doi.org/10.1108/02634500610653991

Anderson, E. W. (1998). Customer satisfaction and word of mouth. Journal of service research, 1(1), 5-17. http://dx.doi.org/10.1177/109467059800100102

Anderson, E. W., Fornell, C., \& Lehmann, D. R. (1994). Customer satisfaction, market share, and profitability: Findings from Sweden. The Journal of Marketing, 53-66. http://dx.doi.org/10.2307/1252310

Bahia, K., \& Nantel, J. (2000). A reliable and valid measurement scale for the perceived service quality of banks. international journal of bank marketing, 18(2), 84-91. http://dx.doi.org/10.1108/02652320010322994

Bai, B., Law, R., \& Wen, I. (2008). The impact of website quality on customer satisfaction and purchase intentions: Evidence from Chinese online visitors. International Journal of Hospitality Management, 27(3), 391-402. http://dx.doi.org/10.1016/j.ijhm.2007.10.008

Baker, D. A., \& Crompton, J. L. (2000). Quality, satisfaction and behavioral intentions. Annals of tourism research, 27(3), 785-804. http://dx.doi.org/10.1016/S0160-7383(99)00108-5

Bearden, W. O., Malhotra, M. K., \& Uscátegui, K. H. (1998). Customer contact and the evaluation of service experiences: Propositions and implications for the design of services. Psychology \& Marketing (1986-1998), 15(8), 793-809.

http://dx.doi.org/10.1002/(SICI) 1520-6793(199812)15:8\%3C793::AID-MAR5\%3E3.0.CO;2-0

Bickart, B., \& Schindler, R. M. (2001). Internet forums as influential sources of consumer information. Journal of interactive marketing, 15(3), 31-40. http://dx.doi.org/10.1002/dir.1014

Bishop Gagliano, K., \& Hathcote, J. (1994). Customer expectations and perceptions of service quality in retail apparel specialty stores. Journal of Services Marketing, 8(1), 60-69. http://dx.doi.org/10.1108/08876049410053311

Bitner, M. J., Brown, S. W., \& Meuter, M. L. (2000). Technology infusion in service encounters. Journal of the Academy of marketing Science, 28(1), 138-149. http://dx.doi.org/10.1177/0092070300281013

Blodgett, J. G., Granbois, D. H., \& Walters, R. G. (1994). The effects of perceived justice on complainants' negative word-of-mouth behavior and repatronage intentions. Journal of Retailing, 69(4), 399-428. http://dx.doi.org/10.1016/0022-4359(93)90015-B

Bolton, R. N. (1998). A dynamic model of the duration of the customer's relationship with a continuous service provider: The role of satisfaction. Marketing science, 17(1), 45-65. http://dx.doi.org/10.1287/mksc.17.1.45

Brady, M. K., \& Cronin Jr, J. J. (2001). Some new thoughts on conceptualizing perceived service quality: a hierarchical approach. Journal of marketing, 65(3), 34-49. http://dx.doi.org/10.1509/jmkg.65.3.34.18334

Brady, M. K., \& Robertson, C. J. (2001). Searching for a consensus on the antecedent role of service quality and satisfaction: an exploratory cross-national study. Journal of Business research, 51(1), 53-60. http://dx.doi.org/10.1016/S0148-2963(99)00041-7

Brady, M. K., Robertson, C. J., \& Cronin, J. J. (2001). Managing behavioral intentions in diverse cultural environments: An investigation of service quality, service value, and satisfaction for American and Ecuadorian fast-food customers. Journal of International Management, 7(2), 129-149. http://dx.doi.org/10.1016/S1075-4253(00)00041-7

Cardozo, R. N. (1965). An experimental study of customer effort, expectation, and satisfaction. Journal of marketing research, 244-249. http://dx.doi.org/10.2307/3150182

Caruana, A. (2002). Service loyalty: the effects of service quality and the mediating role of customer satisfaction. European journal of marketing, 36(7/8), 811-828. http://dx.doi.org/10.1108/03090560210430818

Cheung, C. M., \& Lee, M. K. (2005, August). Consumer satisfaction with internet shopping: a research framework and propositions for future research. In Proceedings of the 7th international conference on Electronic commerce (pp. 327-334). ACM. http://dx.doi.org/10.1145/1089551.1089612

Chung, I. K., \& Lee, M. M. (2003, April). A study of influencing factors for repurchase intention in internet 
shopping malls. In Parallel and Distributed Processing Symposium, 2003. Proceedings. International (pp. 7-pp). IEEE.

Cronin, J. J., Brady, M. K., \& Hult, G. T. M. (2000). Assessing the effects of quality, value, and customer satisfaction on consumer behavioral intentions in service environments. Journal of Retailing, 76(2), 193-218. http://dx.doi.org/10.1016/S0022-4359(00)00028-2

Dresner, M., \& Xu, K. (1995). Customer service, customer satisfaction, and corporate performance. Journal of Business Logistics, 16(1), 23.

Eboli, L., \& Gabriella, M. (2007). Service Quality Attributes Affecting Customer Satisfaction for Bus Transit. Journal of Public Transportation, 10.3. http://dx.doi.org/10.5038/2375-0901.10.3.2

Fornell, C. (1992). A national customer satisfaction barometer: the Swedish experience. The Journal of Marketing, 6-21. http://dx.doi.org/10.2307/1252129

González, M. E. A., Comesaña, L. R., \& Brea, J. A. F. (2007). Assessing tourist behavioral intentions through perceived service quality and customer satisfaction. Journal of Business research, 60(2), 153-160.

Gouthier, M., \& Schmid, S. (2003). Customers and customer relationships in service firms: The perspective of the resource-based view. Marketing Theory, 3(1), 119-143. http://dx.doi.org/10.1177/1470593103003001007

Gronroos, C. (1988). Service quality: the six criteria of good perceived service.Review of business, 9(3), 10.

Guenzi, P., \& Pelloni, O. (2004). The impact of interpersonal relationships on customer satisfaction and loyalty to the service provider. International Journal of Service Industry Management, 15(4), 365-384. http://dx.doi.org/10.1108/09564230410552059

Hartline, M. D., Maxham III, J. G., \& McKee, D. O. (2000). Corridors of influence in the dissemination of customer-oriented strategy to customer contact service employees. Journal of Marketing, 64(2), 35-50. http://dx.doi.org/10.1509/jmkg.64.2.35.18001

Hennig-Thurau, T., \& Klee, A. (1997). The impact of customer satisfaction and relationship quality on customer retention: A critical reassessment and model development. Psychology \& Marketing, 14(8), 737-764. http://dx.doi.org/10.1002/(SICI)1520-6793(199712)14:8\%3C737::AID-MAR2\%3E3.0.CO;2-F

Hu, H. H., Kandampully, J., \& Juwaheer, T. D. (2009). Relationships and impacts of service quality, perceived value, customer satisfaction, and image: an empirical study. The Service Industries Journal, 29(2), 111-125. http://dx.doi.org/10.1080/02642060802292932

Innis, D. E., \& La Londe, B. J. (1994). Customer service: the key to customer satisfaction, customer loyalty, and market share. Journal of Business Logistics, 15, 1-1.

Johnston, R. (2004). Towards a better understanding of service excellence. Managing Service Quality: An International Journal, 14(2/3), 129-133. http://dx.doi.org/10.1108/09604520410528554

Johnston, R. (1995). The determinants of service quality: satisfiers and dissatisfiers. International journal of service industry management, 6(5), 53-71. http://dx.doi.org/10.1108/09564239510101536

Kara, A., Lonial, S., Tarim, M., \& Zaim, S. (2005). A paradox of service quality in Turkey: The seemingly contradictory relative importance of tangible and intangible determinants of service quality. European Business Review, 17(1), 5-20. http://dx.doi.org/10.1108/09555340510576230

Kelley, S. W., \& Davis, M. A. (1994). Antecedents to customer expectations for service recovery. Journal of the Academy of Marketing Science, 22(1), 52-61. http://dx.doi.org/10.1177/0092070394221005

Kim, J., Suh, E., \& Hwang, H. (2003). A model for evaluating the effectiveness of CRM using the balanced scorecard. Journal of interactive Marketing, 17(2), 5-19. http://dx.doi.org/10.1002/dir.10051

Kim, M. K., Park, M. C., \& Jeong, D. H. (2004). The effects of customer satisfaction and switching barrier on customer loyalty in Korean mobile telecommunication services. Telecommunications policy, 28(2), 145-159. http://dx.doi.org/10.1016/j.telpol.2003.12.003

Kouthouris, C., \& Alexandris, K. (2005). Can service quality predict customer satisfaction and behavioral intentions in the sport tourism industry? An application of the SERVQUAL model in an outdoors setting. Journal of Sport \& Tourism, 10(2), 101-111. http://dx.doi.org/10.1080/14775080500223165

Kuo, Y. F., Wu, C. M., \& Deng, W. J. (2009). The relationships among service quality, perceived value, customer satisfaction, and post-purchase intention in mobile value-added services. Computers in human behavior, 
25(4), 887-896. http://dx.doi.org/10.1016/j.chb.2009.03.003

LeBlanc, G., \& Nguyen, N. (1988). Customers' perceptions of service quality in financial institutions. International Journal of Bank Marketing, 6(4), 7-18. http://dx.doi.org/10.1108/eb010834

Lee, H., Lee, Y., \& Yoo, D. (2000). The determinants of perceived service quality and its relationship with satisfaction. Journal of services marketing, 14(3), 217-231. http://dx.doi.org/10.1108/ 08876040010327220

Lee, J., Lee, J., \& Feick, L. (2001). The impact of switching costs on the customer satisfaction-loyalty link: mobile phone service in France. Journal of services marketing, 15(1), 35-48. http://dx.doi.org/10.1108/08876040110381463

Long, M., \& McMellon, C. (2004). Exploring the determinants of retail service quality on the Internet. Journal of services marketing, 18(1), 78-90. http://dx.doi.org/10.1108/08876040410520726

Maxham, J. G. (2001). Service recovery's influence on consumer satisfaction, positive word-of-mouth, and purchase intentions. Journal of Business Research, 54(1), 11-24. http://dx.doi.org/10.1016/S0148-2963(00)00114-4

Murray, D., \& Howat, G. (2002). The relationships among service quality, value, satisfaction, and future intentions of customers at an Australian sports and leisure centre. Sport Management Review, 5(1), 25-43. http://dx.doi.org/10.1016/S1441-3523(02)70060-0

Oh, H. (1999). Service quality, customer satisfaction, and customer value: A holistic perspective. International Journal of Hospitality Management, 18(1), 67-82. http://dx.doi.org/10.1016/S0278-4319(98)00047-4

Olorunniwo, F., Hsu, M. K., \& Udo, G. J. (2006). Service quality, customer satisfaction, and behavioral intentions in the service factory. Journal of Services Marketing, 20(1), 59-72. http://dx.doi.org/10.1108/08876040610646581

Parasuraman, A. (2000). Superior customer service and marketing excellence: two sides of the same success coin. Vikalpa, 25(3), 3-14.

Parasuraman, A., Zeithaml, V. A., \& Berry, L. L. (1985). A conceptual model of service quality and its implications for future research. Journal of Marketing, 41-50. http://dx.doi.org/10.2307/1251430

Parasuraman, A., Zeithaml, V. A., \& Berry, L. L. (1990). Delivering quality service: Balancing customer perceptions and expectations. Delivering quality service: Balancing customer perceptions and expectations. Simon and Schuster.

Patterson, P. G., Johnson, L. W., \& Spreng, R. A. (1996). Modeling the determinants of customer satisfaction for business-to-business professional services. Journal of the academy of marketing science, 25(1), 4-17. http://dx.doi.org/10.1007/BF02894505

Pleger Bebko, C. (2000). Service intangibility and its impact on consumer expectations of service quality. Journal of Services Marketing, 14(1), 9-26. http://dx.doi.org/10.1108/08876040010309185

Robledo, M. A. (2001). Measuring and managing service quality: integrating customer expectations. Managing Service Quality: An International Journal, 11(1), 22-31. http://dx.doi.org/10.1108/09604520110379472

Salanova, M., Agut, S., \& Peiró, J. M. (2005). Linking organizational resources and work engagement to employee performance and customer loyalty: the mediation of service climate. Journal of Applied Psychology, 90(6), 1217. http://dx.doi.org/10.1037/0021-9010.90.6.1217

Santos, J. (2003). E-service quality: a model of virtual service quality dimensions. Managing Service Quality: An International Journal, 13(3), 233-246. http://dx.doi.org/10.1108/09604520310476490

Sharma, A. (2001). Consumer decision-making, salespeople's adaptive selling and retail performance. Journal of Business Research, 54(2), 125-129. http://dx.doi.org/10.1016/S0148-2963(99)00090-9

Shemwell, D. J., Yavas, U., \& Bilgin, Z. (1998). Customer-service provider relationships: an empirical test of a model of service quality, satisfaction and relationship-oriented outcomes. International Journal of Service Industry Management, 9(2), 155-168. http://dx.doi.org/10.1108/09564239810210505

Siddiqi, K. O. (2011). Interrelations between service quality attributes, customer satisfaction and customer loyalty in the retail banking sector in Bangladesh. International Journal of Business and Management, 6(3), 12. http://dx.doi.org/10.5539/ijbm.v6n3p12

Sorce, P., \& Edwards K. (2004). Defining business-to-consumer relationships: The consumer's perspective. The Journal of Database Marketing \& Customer Strategy Management, 11(3), 255-267. 
http://dx.doi.org/10.1057/palgrave.dbm.3240225

Spreng, R. A., \& Mackoy, R. D. (1996). An empirical examination of a model of perceived service quality and satisfaction. Journal of retailing, 72(2), 201-214. http://dx.doi.org/10.1016/S0022-4359(96)90014-7

Steven, A. B., Dong, Y., \& Dresner, M. (2012). Linkages between customer service, customer satisfaction and performance in the airline industry: Investigation of non-linearities and moderating effects. Transportation Research Part E: Logistics and Transportation Review, 48(4), 743-754. http://dx.doi.org/10.1016/j.tre.2011.12.006

Sureshchandar, G. S., Rajendran, C., \& Anantharaman, R. N. (2002). The relationship between service quality and customer satisfaction-a factor specific approach. Journal of services marketing, 16(4), 363-379.

Tam, J. L. (2004). Customer satisfaction, service quality and perceived value: an integrative model. Journal of marketing management, 20(7-8), 897-917. http://dx.doi.org/10.1362/0267257041838719

Taylor, S. A., \& Baker, T. L. (1994). An assessment of the relationship between service quality and customer satisfaction in the formation of consumers' purchase intentions. Journal of retailing, 70(2), 163-178. http://dx.doi.org/10.1016/0022-4359(94)90013-2

Tsiotsou, R. (2006). The role of perceived product quality and overall satisfaction on purchase intentions. $\begin{array}{lllll}\text { International journal of consumer } & \text { studies, } & 30(2), & \text { 207-217. }\end{array}$ http://dx.doi.org/10.1111/j.1470-6431.2005.00477.x

Ulaga, W., \& Chacour, S. (2001). Measuring customer-perceived value in business markets: a prerequisite for marketing strategy development and implementation. Industrial marketing management, 30(6), 525-540. http://dx.doi.org/10.1016/S0019-8501(99)00122-4

Walsh, G., \& Beatty, S. E. (2007). Customer-based corporate reputation of a service firm: scale development and validation. Journal of the Academy of Marketing Science, 35(1), 127-143. http://dx.doi.org/10.1007/s11747-007-0015-7

Woodruff, R. B., Cadotte, E. R., \& Jenkins, R. L. (1983). Modeling consumer satisfaction processes using experience-based norms. Journal of marketing research, 296-304. http://dx.doi.org/10.2307/3151833

Woodside, A. G., Frey, L. L., \& Daly, R. T. (1990). Linking service quality, customer satisfaction, and behavioral intention. Journal of health care marketing, (9), 5-17.

Yang, Z., \& Fang, X. (2004). Online service quality dimensions and their relationships with satisfaction: A content analysis of customer reviews of securities brokerage services. International Journal of Service Industry Management, 15(3), 302-326. http://dx.doi.org/10.1108/09564230410540953

Yavas, U., Bilgin, Z., \& Shemwell, D. J. (1997). Service quality in the banking sector in an emerging economy: a consumer survey. International Journal of Bank Marketing, 15(6), 217-223. http://dx.doi.org/10.1108/02652329710184442

Yeo, G. T., Roe, M., \& Dinwoodie, J. (2008). Evaluating the competitiveness of container ports in Korea and China. Transportation Research Part A: Policy and Practice, 42(6), 910-921. http://dx.doi.org/10.1016/j.tra.2008.01.014

Yi, Youjae, \& Taeshik, G. (2006). The antecedents and consequences of service customer citizenship and badness behavior. Seoul Journal of Business 12(2), 145-176.

Zeithaml, V. A. (1988). Consumer perceptions of price, quality, and value: a means-end model and synthesis of evidence. The Journal of marketing, 2-22. http://dx.doi.org/10.2307/1251446

Zeithaml, V. A. (2002). Service excellence in electronic channels. Managing Service Quality: An International Journal, 12(3), 135-139. http://dx.doi.org/10.1108/09604520210429187

\section{Copyrights}

Copyright for this article is retained by the author(s), with first publication rights granted to the journal.

This is an open-access article distributed under the terms and conditions of the Creative Commons Attribution license (http://creativecommons.org/licenses/by/3.0/). 